\title{
Influence of dry and wet beef maturation on the microbiological quality and safety
}

\section{Influência da maturação a seco e a vácuo na qualidade e segurança microbiológica da carne}

\author{
José Carlos Ribeiro Júnior ${ }^{1 *}$; Isac Gabriel Cunha dos Santos ${ }^{2}$; Bianca Pereira Dias ${ }^{3 ;}$ \\ Wescley Faccini Augusto ${ }^{4}$; Ézio Machado Rodrigues²; \\ Fabrícia Rocha Chaves Miotto ${ }^{1}$
}

\section{Highlights}

Significantly lower microbiological counts were observed in dry-aged meats. Isolation and identification of EPEC, STEC, and EHEC in wet-aged beef. Listeria monocytogenes were viable only in wet-aged beef. Dry maturation improved higher microbiological quality and safety of meat.

\begin{abstract}
The most used methods for the maturation process are vacuum (wet-aged) and dry (dry-aged), which can influence the microbiological quality and safety of meat for consumption. In this study, we aimed to verify the differences in microbiological quality between beef (Longissimus dorsi) that was wet-aged and dry-aged for 30 days, by quantification of indicator microorganism groups and molecular identification of Salmonella, Listeria monocytogenes, and diarrheagenic Escherichia coli. This study verified that the meat matured by the dry-aged method showed significantly lower counts of total coliforms, aerobic mesophiles, psychrotrophs, and molds and yeasts as compared to wet-aged meat. While the Salmonella spp. was not isolated in any beef sample, L. monocytogenes and enteropathogenic E. coli (EPEC), and shiga toxin-producing E. coli (STEC) and enterohemorrhagic $E$. coli (EHEC) were isolated only from wet-aged beef. Thus, it was concluded that the superficial dehydration of the meat during dry-aged maturation, if carried out correctly and hygienically, confers higher microbiological quality and can reduce the occurrence of microbiological hazards.
\end{abstract}

Key words: Coliforms. Escherichia coli. Foodborne pathogens. Listeria monocytogenes. Psychrotrophs.

\footnotetext{
1 Profs., Universidade Federal do Tocantins, UFT, Escola de Medicina Veterinária e Zootecnia, EMVZ, Campus universitário de Araguaína, Araguaína, TO, Brasil. E-mail: jcribeiro@uft.edu.br; fabriciarchaves@uft.edu.br

2 Discentes do Curso de Mestrado do Programa de Pós-Graduação em Sanidade Animal e Saúde Pública nos Trópicos, PPGSaspt, UFT, Araguaína, TO, Brasil. E-mail: isacgabrielsc@gmail.com; ezio1970@hotmail.com

3 Discente do Curso de Graduação em Medicina Veterinária, UFT, Araguaína, TO, Brasil. E-mail: biianca.p.dias@gmail.com

4 Pós-Doutorando do Programa de Pós-Graduação em Ciência Animal Tropical, PPGCAT, UFT, Araguaína, TO, Brasil. E-mail: wescleyfaccini@hotmail.com

* Author for correspondence
}

Received: May 20, 2020 - Approved: Nov. 02, 2020 


\section{Resumo}

A maturação da carne agrega características sensoriais desejáveis ao consumidor. Os métodos mais utilizados são a vácuo (wet-aged) e à seco (dry-aged), que podem influenciar na qualidade e segurança microbiológica da carne para o consumo. $O$ objetivo desse estudo foi verificar as diferenças de qualidade microbiológica entre cortes de contra-filé (Longissimus dorsi) maturados a vácuo e a seco por 30 dias, através da quantificação de grupos de micro-organismos indicadores e identificação molecular de Samonella, Listeria monocytogenes e Escherichia coli diarreiogênica. A carne maturada a seco apresentou contagens significativamente menores de coliformes totais, aeróbios mesófilos, psicrotróficos e bolores e leveduras em relação à carne maturada a vácuo. Salmonella spp. não foi isolada de nenhuma das amostras de carne analisadas. L. monocytogenes e E. coli enteropatogênica (EPEC), E. coli produtora de toxina shiga (STEC) e E. coli enterohemorrágica (EHEC) foram identificadas somente das carnes maturadas a vácuo. A desidratação superficial das peças durante a maturação a seco, desde que realizada de forma correta e higiênica, pode conferir maior qualidade e menor risco microbiológico para o consumo.

Palavras-chave: Coliformes. Escherichia coli. Listeria monocytogenes. Patógenos alimentares. Psicrotróficos.

\section{Introduction}

Meat tenderness is one of the sensory characteristics that improves the palatability of meat and hence is most demanded by the consumer. This characteristic is determined by several factors, such as age, breed, and sex of the animal. The process of maturation plays a very important role in ensuring a product of high sensory quality (Monsón, Sañudo, \& Sierra, 2005). This process is carried out by keeping the meat under refrigerated conditions for up to 30 days after the animal is slaughtered. During this period, the action of endogenous proteases, such as cathepsins, proteasomes, and caspases, in addition to the calpain system, which is mainly responsible for post mortem proteolysis, promote meat tenderization (Krause et al., 2011).

Several methods can be used for the meat maturation process, adding value to the meat while increasing and preserving its quality (Ortigues-Marty et al., 2006). The maturation of meat in parts by vacuum packaging is the most frequently used method. This method limits the multiplication of putrefying aerobic microorganisms and favors the multiplication of lactic acid bacteria, which produce acids, peroxides, and bacteriocins that inhibit the multiplication of deteriorating microorganisms (Pidcock, Heard, \& Henriksson, 2002; Marty, Buchs, Eugster-Meier, Lacroix, \& Meile, 2012), thereby increasing the shelf life of the meat (Damez \& Clerjon, 2008). However, since the polyethylene packaging preserves the wetness of the meat (wet-aged), the pathogens and contaminants in the prepackaged meat continue to be maintained.

As an alternative, dry-aged beef has become more popular, in which the meat pieces, boneless or not, are subjected to refrigeration without packaging (Lautenschlaeger, 2012). This can results in superficial dehydration of the piece which negatively impacts the multiplication and viability of microorganisms with pathogenic and spoilage potential (Dashdorj, Tripathi, Cho, Kim, \& Hwang, 2016). 
Microorganisms are known to be capable of contaminating animal carcasses during slaughter and processing (Koutsoumanis \& Sofos, 2004; Van Ba et al., 2018; Mezali, Mebkhout, Nouichi, Boudjellaba, \& Hamdi, 2019). Such microorganisms can prove pathogenic and pose a risk to the consumer if processed incorrectly, or even be the source of infection in the case of crosscontamination. The presence of certain groups of microorganisms can indicate the quality of and safety of a food product for consumption (Alnajrani et al., 2018).

The objective of the present study was to assess the microbiological quality and safety of wet and dry-aged beef by evaluating the indicator microorganisms and pathogens in meat matured for 30 days under refrigerated conditions.

\section{Materials and Methods}

Twenty-eight pieces of beef (Longissimus dorsi) obtained from cattle belonging to the School of Veterinary Medicine and Animal Science of the Federal University of Tocantins, in Araguaína, Brazil, were evaluated from July to September 2019. The animals were slaughtered in a slaughterhouse under Brazilian federal sanitary inspection. After the carcasses were kept refrigerated for 24 hours at $2^{\circ} \mathrm{C}$, the beef pieces (one loin per carcass) were sent to the refrigerating chamber of the same University, which maintains a controlled temperature of $4^{\circ} \mathrm{C}$ and that had been disinfected before the experiment.

The 28 pieces were divided into four groups comprising of seven units, considering that seven animals were slaughtered each time, with an interval of 14 days. Each piece was aseptically divided in half. Half of the piece was maintained with bone and the other half deboned and was vacuum-packed in sterile plastic packaging. All the halves pieces were kept under constant refrigeration at $4^{\circ} \mathrm{C}$ in a refrigerating chamber for a period of 30 days for simultaneous wet and dry maturation. The pieces were kept on stainless steel shelves and the temperature was constantly controlled with internal and external thermometers. The microbiological analysis of the pieces was not carried out before the maturation process.

After the maturation period, the four groups of wet and dry-aged half pieces were evaluated providing for adequate repetition. Sampling was done by extracting $\approx 7.2 \mathrm{~g}$ of each piece amounting to a two $25 \mathrm{~g}$ aliquots from the group comprising of the dry-aged pieces and another two $25 \mathrm{~g}$ aliquots from the group comprising of the wet-aged pieces. The aliquots were, therefore, representative of all the 28 pieces of meat.

Each $25 \mathrm{~g}$ sample aliquots were homogenized in Stomacher, one with $225 \mathrm{~mL}$ of buffered peptone water $\left(\mathrm{H}_{2} \mathrm{Op}\right)$ (Acumedia, Baltimore, USA) and another with $225 \mathrm{~mL}$ of Half Fraser broth (Acumedia) for 180 seconds in a sterile plastic bag. The aliquot homogenized with $\mathrm{H}_{2} \mathrm{Op}\left(10^{-1}\right)$ was serially diluted up to $10^{-9}$ in saline solution $(0.85 \%)$.

Microorganisms belonging to the groups of total and thermotolerant coliforms were evaluated by the most probable number (MPN) method according to the American Public Health Association's Compendium of Methods for the Microbiological Examination of Foods (Kornacki, 2015). Total coliforms were evaluated in Brilliant-Green Lactose Bile broth (Difco, Maryland, USA) at $35^{\circ} \mathrm{C}$. The Escherichia coli (EC) broth (Difco) tubes were incubated at 
$45^{\circ} \mathrm{C}$ for detection of thermotolerant coliforms. Samples from the positive EC broth tubes were applied on eosin methylene blue (EMB) agar (Oxoid, Basingstoke, Hampshire, England) for isolation of Escherichia coli (characteristic green colonies with metallic luster).

The mesophilic aerobes were counted using the pour-plate method in duplicates. One $\mathrm{mL}$ of the sample was inoculated in plate counting ágar (PCA) and incubated for 48 hours at $35 \pm 1^{\circ} \mathrm{C}$ (Ryser, 2015). Psychrotrophs were quantified by inoculating $0.1 \mathrm{~mL}$ of the sample in PCA and incubating for 10 days at 7 $\pm 1^{\circ} \mathrm{C}$ (APHA, 2015c). Molds and yeasts were quantified after inoculating $0.1 \mathrm{~mL}$ sample on dichloranrose bengal chloramphenicol (DRBC) (Oxoid, Basingstoke, UK) agar and incubating for five days at $25 \pm 1^{\circ} \mathrm{C}$.

The statistical analysis of the microbiological counts was performed using the Statistica Software (StatSoft, OK, USA) v. 6.0. Student's T test with $\alpha=5 \%$ was used for the analysis.
The detection of Salmonella spp. was carried out according to the ISO 6579 (International Organization for Standardization [ISO], 2005) method and the Listeria spp. detection was performed according to the ISO 11290 (2004) method, and both were modified. Characteristic colonies of Salmonella spp. on xylose lysine deoxycholate (XLD) (Acumedia) and Salmonella-Shigella agar plates (HiMedia, Mumbai, India) and suggestive colonies of Listeria spp. on Oxford (Acumedia) and Listeria Seletive (HiMedia, Mumbai, India) agar plates were recovered in brain heart broth $(\mathrm{BHI})$ (Acumedia) and subjected to DNA extraction (Ribeiro et al., 2016). Polymerase chain reaction (PCR) was used to confirm the genus and species of the isolates using specific primers and amplification conditions as presented in Table 1. The PCR reactions were performed with a final reaction volume of $25 \mu \mathrm{L}$ and the component volumes and conditions were the same as those described by Ribeiro et al. (2019). 


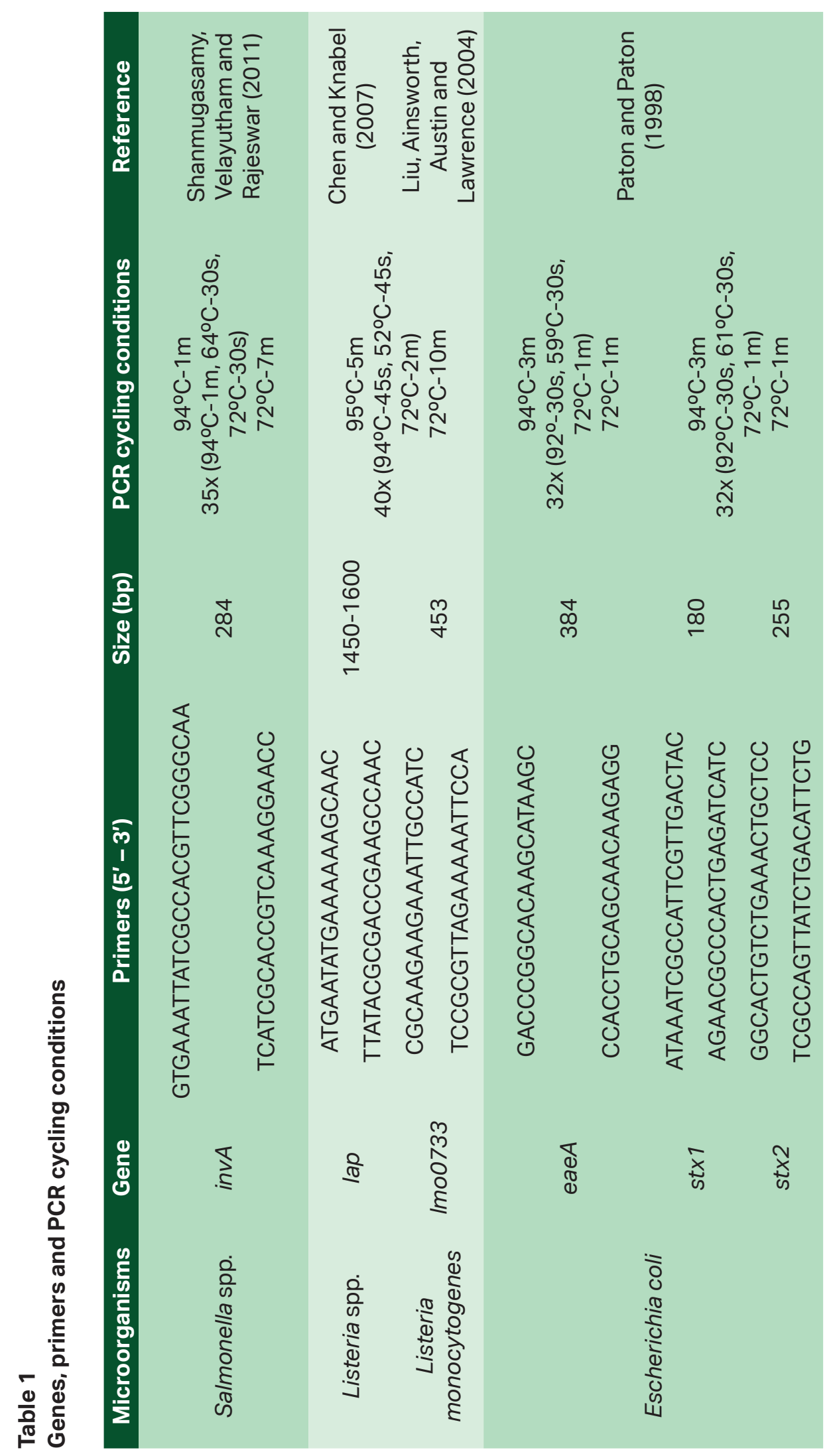


The virulence factors of suggestive E. coli isolates, encoded by eaeA, stx 1 , and stx2 genes, were investigated by molecular approaches described by Ribeiro et al. (2019). This approach (shown in Table 1) enabled the confirmation of enteropathogenic $E$. coli (EPEC), enterohemorrhagic E. coli (EHEC) and shiga toxin-producing E. coli (STEC) in the meat samples.

\section{Results and Discussion}

The results of the microbiological counts of the different groups of indicator microorganisms in the wet and dry-aged beef samples are shown in Table 2.

Table 2

\section{Quantifications of quality indicator microorganisms in wet and dry-aged matured meat samples}

\begin{tabular}{|c|c|c|c|}
\hline Groups & Variations $^{1}$ & Wet-aged $^{2}$ & Dry-aged $^{2}$ \\
\hline \multirow{3}{*}{ Coliforms at $30^{\circ} \mathrm{C}(\mathrm{MPN} / \mathrm{g})$} & M & 460 & 29 \\
\hline & $\mathrm{m}$ & 9,1 & $<3$ \\
\hline & Mean (SE) & $146^{a}(106)$ & $16^{\mathrm{b}}(9)$ \\
\hline \multirow{3}{*}{ Coliforms at $45^{\circ} \mathrm{C}(\mathrm{MPN} / \mathrm{g})$} & M & 15 & 29 \\
\hline & $\mathrm{m}$ & $<3$ & $<3$ \\
\hline & Mean (SE) & $9.3^{\mathrm{a}}(2.8)$ & $16^{\mathrm{a}}(9)$ \\
\hline \multirow{3}{*}{ Aerobic mesophiles (CFU/g) } & $M$ & $9 \times 10^{8}$ & $3.2 \times 10^{4}$ \\
\hline & $\mathrm{m}$ & $9 \times 10^{6}$ & $2.1 \times 10^{3}$ \\
\hline & Mean (SE) & $3 \times 10^{8 a}\left(8 \times 10^{3}\right)$ & $1.3(0.8) \times 10^{4 b}$ \\
\hline \multirow{3}{*}{ Psychrotrophs (CFU/g) } & M & $5.8 \times 10^{8}$ & $1.7 \times 10^{5}$ \\
\hline & $\mathrm{m}$ & $6.4 \times 10^{7}$ & $8 \times 10^{2}$ \\
\hline & Mean (SE) & $2.4(1.4) \times 10^{8 a}$ & $6.3(4.7) \times 10^{4 b}$ \\
\hline \multirow{3}{*}{ Molds and yeasts (CFU/g) } & M & $8.7 \times 10^{7}$ & $2.7 \times 10^{5}$ \\
\hline & $\mathrm{m}$ & $1.6 \times 10^{5}$ & $1.9 \times 10^{4}$ \\
\hline & Mean (SE) & $3.8(2.1) \times 10^{7 a}$ & $1(0.6) \times 10^{5 b}$ \\
\hline
\end{tabular}

${ }^{1} \mathrm{M}=$ maximum; $\mathrm{m}=$ minimum; $\mathrm{SE}=$ standard error; ${ }^{2}$ Superscript different letters on the same line indicate a significant difference in Student's $T$ test at the $5 \%$ level of significance.

Vacuum-matured (wet-aged) meat samples presented significantly higher counts of total coliforms, mesophilic aerobes, psychrotrophs, and molds and yeasts as compared to dry-aged meat samples. This indicates that dry maturation, as long as it is properly performed and in adequate environmental sanitary conditions, is better at preserving the microbiological quality of the meat.

Vacuum packaging can create an environment for preserving moisture and consequently, favor the maintenance and multiplication of contaminating microbiota, even with the maintenance of low temperature 
and $\mathrm{pH}$. Mateus, Santos, Viana, Camillo and Kessler (2018) have shown that vacuummatured meat attains a pH of 5.35 within the first nine days of maturation, which may prove to be a limiting factor for the microbial multiplication log phase. On the other hand, the superficial dehydration of dry-aged meat pieces under refrigerated conditions may be responsible for the low prevalence of contaminating microorganisms, especially mesophiles. In addition, the recent work done by Lee et al. (2019) has demonstrated that differences in air flow promotes variations in dehydration levels of the crust of dry-aged beef and this has an effect on the microbial composition and, consequently, on its sensory properties.

The coliforms growing at $45^{\circ} \mathrm{C}$ were the only ones that did not show inferior results in the quantification estimate of the dry-aged meat as compared to the wet-aged meat, as shown in Table 2. No statistically significant difference was observed. The current Brazilian legislation that regulates food commerce (ANVISA, 2001) recommends a maximum coliform count of $45^{\circ} \mathrm{C}$ at $5 \times 10^{3} / \mathrm{g}$ for wet-aged meats, which was not obtained for any of the samples.

Thermotolerant coliforms $\left(45^{\circ} \mathrm{C}\right)$ belong to a specific group of total coliforms that indicate possible contamination of fecal origin. Fecal contamination in meat samples is confirmed by isolation of $E$. coli, the only coliform thriving at $45^{\circ} \mathrm{C}$ that has fecal origin. The new Brazilian legislation, published in December 2019 (ANVISA, 2019), recommends the detection of $E$. coli in matured as well as non-matured meats instead of thermotolerant coliforms.

E. coli suggestive isolates were not recovered from the dry-aged meat samples. This indicates that coliforms at $45^{\circ} \mathrm{C}$ isolated from dry-matured meats possibly belong to the genera Citrobacter, Enterobacter or Klebsiella, thermotolerant coliforms that do not have specific fecal origin (Dufour, 1977).

Sixty-nine $E$. coli suggestive isolates were recovered from the vacuum matured meat samples indicating fecal contamination in meat probably before the maturation process, since the packaging was sterile and its integrity observed in the vacuum maintenance did not allow the inclusion of environmental contaminants during the maturation period. Such contamination is considered normal in meat immediately after slaughter, since the slaughtering processes and environment is not always conducive for total prevention of contamination of the carcass by fecal content during evisceration and skinning, in addition to possible contamination of the water used in the slaughter process. The Brazilian legislation (ANVISA, 2019) allows the presence of up to $100 \mathrm{CFU} / \mathrm{g}$ of $E$. coli in beef in to two of five samples in the sampling plan. The environment of the vacuum aging method of beef maturation used in the present work, however, allowed these isolates to remain viable even after 30 days under refrigerated conditions, due to the preserved surface moisture being higher as compared to that in dry-aged meat.

E. coli suggestive isolates were characterized based on their pathogenicity by analyzing the main virulence genes. It was found that three isolates contained the eae $A$ gene, which is characteristic of EPEC, while another isolate contained the stx 1 gene which is a characteristic of STEC. The stx 2 gene was not found in any of the isolates. One isolate had both genes (eae $A$ and stx 1 ), which is a characteristic of EHEC, thereby indicating its presence among the $E$. coli isolates obtained from the vacuum-aged samples. 
As reported previously (Etcheverría et al., 2010), these microorganisms make up the bovine enteric microbiota and are responsible for contamination during evisceration and skinning. Therefore, such contamination of fresh meat by $E$. coli can be blamed on the slaughter processes.

Thus, it can be inferred that if fresh meat contaminated with $E$. coli is matured under vacuum conditions, the isolates remain viable after 30 days, thereby, making this meat a potential source of enteropathogens for the consumer. On the other hand, absence of $E$. coli suggestive isolates in the dry-aged meat, in this experiment performed in a hygienic and controlled way, indicates that dry maturation makes the $E$. coli isolates non-viable after 30 days, thereby, reducing the risk of the dryaged meat causing foodborne infections and/ or toxinfection, that is, rendering it safer for consumption.

A total of 13 characteristic colonies of the Salmonella spp. were isolated in the wetaged meat samples, however Salmonella spp. was not confirmed in the genus-specific PCR.

This result complies with the fact that this genus is more prevalent in poultry and pork meat, usually not present in bovine enteric microbiota thereby limiting carcass contamination by this microorganism. The quick processing of fresh meat under aseptic conditions (Althaus, Zweifel, \& Stephan, 2017; Pesciaroli et al., 2017) also contributes largely to the absence of the Salmonella spp.. However, this study does not provide sufficient evidence to indicate that vacuum or dry maturation is responsible for reducing the microbiological risk posed by the presence of Salmonella spp., warranting the need for further studies to assess the growth and characteristics of this organism during meat maturation.
L. monocytogenes was identified in one of the wet-aged meat samples. Four hundred and nineteen isolates of this organism were recovered from the samples of the present study, including wet-aged and dry-aged meat. The large number of isolates was the result of the recovery of all characteristic isolates in the selective culture media. Of these, 107 isolates from one wet-aged meat sample showed positive results in genus and species-specific PCRs.

L. monocytogenes is a microorganism of public health importance as it is mainly responsible for cases of abortion and bacterial meningitis (Radoshevich \& Cossart, 2018). Being a biofilm-forming microorganism, it is known to reduce the effectiveness of the industrial sanitation procedures aimed at controlling contamination (Schäfer et al., 2017). This poses a challenge in obtaining uncontaminated meat and other animal-origin food in an industrial environment.

In addition, this species is known to be psychrotrophic, which increases the potential of chilled foods to be carriers of this pathogen (Rodríguez López, Bernárdez, Rodríguez-Herrera, Comesaña, \& Cabo, 2019). Refrigeration is known to be the main preservation method for products of animal origin, and is of fundamental importance in the process of meat maturation. Despite the lack of prior microbiological analysis of the meat before the maturation process, the results of this study indicated that dry maturation sufficiently reduced the risk of the presence of $L$. monocytogenes, assuming that the samples before maturation had the same microbiological content and that the plastic packaging used for vacuum-aging meat was sterile. 
The study by Lautenschlaeger (2012) demonstrated that there was little influence of dry and wet maturation on the physical and chemical properties of meat, such as $\mathrm{pH}$, weight loss through cooking, tenderness, flavor, and juiciness. The author reports a greater influence of the conditions of the muscle before maturation than of the maturation process employed. However, the present work has clearly indicated that dry maturation of beef improves the microbiological quality of meat and reduces the risk of foodborne infections owing to the significantly reduced counts of most microorganisms that indicate quality. This is also supported by the finding that dryaged meat did not indicate the recovery of enteropathogens or L. monocytogenes, as against wet-aged meat.

Further studies are necessary to verify the differences in the quantifications of the indicator microorganisms during varying maturation periods and the behavior of microbial pathogens during maturation under different conditions of temperature, humidity, and $\mathrm{pH}$. Such studies could enable food processing companies to decide and use processes of beef maturation that are more appropriate in order to provide consumers with better and safer products.

\section{Conclusions}

Dry meat maturation is a preferred maturation processasitreduces contamination by microorganisms from the groups of total coliforms, mesophilic aerobes, psychrotrophs and molds and yeasts. Wet-aged matured meat, as compared to dry-aged meat, in addition to showing higher counts of indicator microorganisms, presents the risk of causing foodborne diseases and intoxications, if not appropriately thermally processed, due to the presence of pathogens such as EPEC, STEC, EHEC and L. monocytogenes.

\section{Funding}

This study was supported by the following Brazilian institutes: the National Council of Scientific and Technological Development (CNPq), Research Support Foundation of Tocantins State (FAPT, Palmas, Tocantins, Brazil) and Research Program for SUS (PPSUS, Brasília, Brazil).

\section{References}

Alnajrani, M., Hanlon, K., English, A., Fermin, K., Brashears, M. M., \& Echeverry, A. (2018). Comparing the recovery of indicator microorganisms from beef trimmings using swabbing, rinsing, and grinding methodologies. Meat and Muscle Biology, 2(1), 154-161. doi: 10.22175/ mmb2017.09.0047

Althaus, D., Zweifel, C., \& Stephan, R. (2017). Analysis of a poultry slaughter process: influence of process stages on the microbiological contamination of broiler carcasses. Italian Journal of Food Safety, 6(4), 190-194. doi: 10.4081/ijfs.2017.7097

ANVISA. Agência Nacional de Vigilância Sanitária (2001). Resolução-RDC n¹2, de 02/01/01. Regulamento Técnico sobre Padrões Microbiológicos para Alimentos. Diário Oficial da União, 1, 45-53.

ANVISA. Agência Nacional de Vigilância Sanitária (2019). Instrução normativa n 60 , de 23/12/2019. Padrões microbiológicos para alimentos. Diário Oficial da União, 249, 133. 
Chen, Y., \& Knabel, S. J. (2007). Multiplex PCR for simultaneous detection of bacteria of the genus Listeria, Listeria monocytogenes, and major serotypes and epidemic clones of L. monocytogenes. Applied and Environmental Microbiology, 73(19), 6299-6304. doi: 10.1128/AEM.00961-07

Damez, J. L., \& Clerjon, S. (2008). Meat quality assessment using biophysical methods related to meat structure. Meat Science, 80(1), 132-149. doi: 10.1016/j. meatsci.2008.05.039

Dashdorj, D., Tripathi, V. K., Cho, S., Kim, Y., \& Hwang, I. (2016). Dry aging of beef; Review. Journal of Animal Science and Technology, 58(20), 20. doi: 10.1186/ s40781-016-0101-9

Dufour, A. P. (1977). Escherichia coli: the fecal coliform. Bacterial indicators/health hazards associated with water (pp. 48-58). Philadelphia: ASTM International.

Etcheverría, A. I., Padola, N. L., Sanz, M. E., Polifroni, R., Krüger, A., Passucci, J.,... Parma, A. E. (2010). Occurrence of Shiga toxin-producing E. coli (STEC) on carcasses and retail beef cuts in the marketing chain of beef in Argentina. Meat Science, 86(2), 418-421. doi: 10.1016/j. meatsci.2010.05.027

International Organization for Standardization (2002). ISO 6579. Microbiology of food and animal feeding stuffs - horizontal method for detection of Salmonella spp. (4nd ed.). Amendment 1:2007.

International Organization for Standardization (2004). ISO 11290-1:1996. Microbiology of food and animal feeding stuffs horizontal method for the detection and enumeration of Listeria monocytogenes. Part 1: Detection method. Amendment $1: 2004$.
Kornacki, J. L., Gurtler, J. B., \& Stawick, B. A (2015). American Public Health Association Enterobacteriaceae, coliforms, and Escherichia coli as quality and safety indicators. Chapter 9. In Compendium of Methods for the Microbiological Examination of Foods.

Koutsoumanis, K., \& Sofos, J. N. (2004). Microbial contamination of carcasses and cuts. Encyclopedia of Meat Sciences, $67(1)$, 1624-1629. doi: 10.1016/B0-12464970-X/00070-2

Lautenschlaeger, R. (2012). Latest trends in beef maturation-Dry-aged versus wet-aged beef. Proceedings of the 58th International Congress of Meat Science and Technology, International Competence Center on Meat Quality, Department of Safety and Quality of Meat, Max Rubner-Institut, Germany.

Lee, H. J., Yoon, J. W., Kim, M., Oh, H., Yoon, Y., \& Jo, C. (2019). Changes in microbial composition on the crust by different air flow velocities and their effect on sensory properties of dry-aged beef. Meat Science, 153(1), 152-158. doi: 10.1016/j. meatsci.2019.03.019.

Liu, D., Ainsworth, A. J., Austin, F. W., \& Lawrence, M. L. (2004). Use of PCR primers derived from a putative transcriptional regulator gene for species-specific determination of Listeria monocytogenes. International Journal of Food Microbiology, 91(3), 297-304. doi: 10.1016/j.ijfoodmicro.2003.07.004

Marty, E., Buchs, J., Eugster-Meier, E., Lacroix, C., \& Meile, L. (2012). Identification of staphylococci and dominant lactic acid bacteria in spontaneously fermented Swiss meat products using PCR-RFLP. Food Microbiology, 29(2), 157-166. doi: 10.1016/j.fm.2011.09.011 
Mateus, K. A., Santos, M. R., Viana, L. R., Camillo, D. M., \& Kessler, J. D. (2018). Período de maturação promove alterações dos parâmetros físico-químicos e microbiológicos da carne bovina submetida a vácuo. Revista de Ciências Agroveterinárias, 17(4), 599-602. doi: $10.5965 / 223811711732018599$

Mezali, L., Mebkhout, F., Nouichi, S., Boudjellaba, S., \& Hamdi, T. M. (2019). Serotype diversity and slaughterhouse-level risk factors related to Salmonella contamination on poultry carcasses in Algiers. The Journal of Infection in Developing Countries, 13(5), 384-393. doi: 10.3855/jidc. 10450

Monsón, F., Sañudo, C., \& Sierra, I. (2005). Influence of breed and ageing time on the sensory meat quality and consumer acceptability in intensively reared beef. Meat Science, 71(3), 471-479. doi: 10.1016/j. meatsci.2005.04.026

Ortigues-Marty, I., Thomas, E., Prévéraud, D. P., Girard, C. L., Bauchart, D., Durand, D., \& Peyron, A. (2006). Influence of maturation and cooking treatments on the nutritional value of bovine meats: Water losses and vitamin B12. Meat Science, 73(3), 451458. doi: 10.1016/j.meatsci.2006.01.003

Paton, A. W., \& Paton, J. C. (1998). Detection and characterization of shiga toxigenic Escherichia coli by using multiplex PCR assays for stx1, stx2, eaeA, enterohemorrhagic $E$. coli hlyA, rfb 0111, and rfb 0157. Journal of Clinical Microbiology, 36(2), 598-602. doi: 10.1128/JCM.36.2.598-602.1998

Pesciaroli, M., Cucco, L., De Luca, S., Massacci, F. R., Maresca, C., Medici, L.,... Magistrali, C. F. (2017). Association between pigs with high caecal Salmonella loads and carcass contamination. International Journal of Food Microbiology, 242(1), 82-86. doi: 10.1016/j.jjfoodmicro.2016.11.021
Pidcock, K., Heard, G. M., \& Henriksson, A. (2002). Application of nontraditional meat starter cultures in production of Hungarian salami. International Journal of Food Microbiology, 76(1), 75-81. doi: 10.1016/ S0168-1605(02)00002-8

Radoshevich, L., \& Cossart, P. (2018). Listeria monocytogenes: towards a complete picture of its physiologyand pathogenesis. Nature Reviews Microbiology, 16(1), 3246. doi: 10.1038/nrmicro.2017.126

Ribeiro, J. C., Jr., Silva, F. F., Lima, J. B. A., Ossugui, E. H., Teider, P. I., Jr., Campos, A. C. L. P.,... Beloti, V. (2019). Molecular characterization and antimicrobial resistance of pathogenic Escherichia coli isolated from raw milk and Minas Frescal cheeses in Brazil. Journal of Dairy Science, 102(12), 10850-10854. doi: 10.3168/ jds.2019-16732

Ribeiro, J. C., Jr., Tamanini, R., Soares, B. F., Oliveira, A. M., Silva, F. G., Silva, F. F.,... Beloti, V. (2016). Efficiency of boiling and four other methods for genomic DNA extraction of deteriorating sporeforming bacteria from milk. Semina: Ciências Agrárias, 37(5), 3069-3078. doi: 10.5433/1679-0359.2016v37n5 p3069

Rodríguez López, P., Bernárdez, M., RodríguezHerrera, J. J., Comesaña, Á. S., \& Cabo, M. L. (2019). Identification and metagenetic characterisation of Listeria monocytogenes-harbouring communities present in food-related industrial environments. Food Control, 95(1), 6-17. doi: 10.1016/j.foodcont.2018. 07.023

Ryser, E. T., \& Schuman, J. D (2015). American Public Health Association. Mesophilic aerobic plate count. Chapter 8. In Compendium of Methods for the Microbiological Examination of Foods. 
Schäfer, D. F., Steffens, J., Barbosa, J., Zeni, J., Paroul, N., Valduga, E.,... Cansian, R. L. (2017). Monitoring of contamination sources of Listeria monocytogenes in a poultry slaughterhouse. LWT, 86(1), 393398. doi: 10.1016/j.Iwt.2017.08.024

Shanmugasamy, M., Velayutham, T., \& Rajeswar, J. (2011). Inv A gene specific PCR for detection of Salmonella from broilers. Veterinary World, 4(12), 562-564. doi: 10.5455/vetworld.2011.562-564
Van Ba, H., Seo, H. W., Pil-Nam, S., Kim, Y. S., Park, B. Y., Moon, S. S.,... Kim, J. H. (2018). The effects of pre-and post-slaughter spray application with organic acids on microbial population reductions on beef carcasses. Meat Science, 137(1), 16-23. doi: 10.1016/j.meatsci.2017.11.006

Vasavada, P. C., \& Critzer, F. J (2015). American Public Health Association. Psychrotrophic Microorganisms. Chapter 13. In Compendium of Methods for the Microbiological Examination of Foods. 